\title{
Effect of Hot Water Dipping and Polyamines on Activity of Ripening Enhancer Enzymes during Storage of Ber
}

\author{
Hukam Raj Saini*, Sunil Pareek, D.K. Sarolia and Mukesh Nagar
}

Department of Horticulture, Rajasthan College of Agriculture, MPUA\&T, Udaipur 313001,

Rajasthan, India

*Corresponding author

\section{A B S T R A C T}

Effect of hot water dipping and polyamines on activity of ripening enhancer enzymes during storage of ber was carried out in the Department of Horticulture, Rajasthan College of Agriculture, Udaipur. Experiment was conducted from January 2013 to April 2013. Experiment consisted of 9 treatment combinations of water dipping at 20,35 and $45^{\circ} \mathrm{C}$ and polyamine treatments (Spm, Spd and Put) at $1 \mathrm{mM} \mathrm{L}^{-1}$ concentrations. The uniform sized

Keywords

Polygalacturonase, Polyphenol oxidase, Phenylalanine ammonia lyase and Chilling injury.

\section{Article Info}

Accepted:

12 September 2017

Available Online:

10 November 2017 fully matured but unripe fruits of ber cv. 'Gola' at color turning stage were used for treatments and treated fruits stored at $6^{\circ} \mathrm{C}$ temperature. These treatment combinations were evaluated under factorial completely randomized design with three replications. The stored fruit examined at 7 days interval up to 35 days for various change in ripening associate enzyme activity and chilling injury index. The activities of phenylalanine ammonia-lyase (PAL, EC 4.3.1.5), polyphenol oxidase (PPO, EC 1.10.3.1) and polygalacturonase (PG, EC 3.2.1.15) were analyzed during the storage. It was observed that $45^{\circ} \mathrm{C}$ hot water + putrescine $\left(1 \mathrm{mM} \mathrm{L}{ }^{-1}\right)$ treatment combination was found to be better in maintaining desirable enzymatic activity than other treatment combinations. The chilling injury was also minimum in the treatment combination $45^{\circ} \mathrm{C}$ hot water + putrescine $\left(1 \mathrm{mM} \mathrm{L}^{-1}\right)$. In dipping for $5 \mathrm{~min}$ at $45^{\circ} \mathrm{C}$ hot water with putrescine $1 \mathrm{mM} \mathrm{L}^{-1}$, the maximum or minimum activity of PPO, PAL and PG were found in Gola ber fruit to be better than other treatment combinations during the storage at $6^{\circ} \mathrm{C}$. During the storage, the activity of PPO, PAL and PG were increased during storage at $6^{\circ} \mathrm{C}$ for 35 day. Finally this study indicates that ber fruit can be stored at $6^{\circ} \mathrm{C}$ for 35 days with using $\mathrm{W}_{3} \mathrm{P}_{3}\left(45^{\circ} \mathrm{C}\right.$ hot water + putrescine $1 \mathrm{mM}$ $\mathrm{L}^{-1}$ ) treatment combination by maintaining ripening associated enzymatic activity and minimum chilling injury index.

\section{Introduction}

Ber (Ziziphus mauritiana Lamk.) is one of the important minor fruits of India. It belongs to the family Rhamnaceae and is native to central Asia (Morton, 1987). It is being considered as poor man's apple due to high nutritive value. Rajasthan is one of the leading state of India in ber production with 28,800 tonnes of fruits from the acreage of
3,200 hectares (Anon., 2009). However, in an estimate $Z$. mauritiana, $Z$. nummularia and $Z$. rotundifolia covers an area of 20,000 hectare in Rajasthan (Pareek et al., 2009a). Nutritionally, ber fruit is widely acclaimed for its rich source of ascorbic acid (70-165 mg $100 \mathrm{~g}^{-1}$ ) (Bal and Mann, 1978). Apart from this, it is a good source of essential minerals 
like Ca, P and Fe (Pareek, 1983). Pulp contains 12.8-13.6 per cent carbohydrates (Jawanda et al., 1981). 'Gola' ber contains 20.10 per cent TSS, 0.34 per cent acidity,

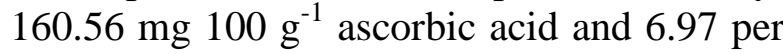
cent total sugars (Pareek et al., 2002). Extensive studies have been carried out to prepare various processed products from ber fruit such as candy, preserve, dehydrated products including osmo-dehydrated products, jam, jelly, juice, squash and pickle (Pareek and Yahia, 2013). The previous study carried out in this laboratory on storage temperatures of 'Gola' ber fruit showed that shelf life can be increased at lower temperatures of $6^{\circ} \mathrm{C}$, but chilling injury $(\mathrm{CI})$ limits the quality of fruit (Jat et al., 2013).

Polyamines are organic cations containing amino groups that are present in all eukaryotic cells and intimately involved in, and required for, distinct biological functions. An increasing body of evidence indicates that the regulation of the cellular PAs is a central convergence point for the multiple signaling pathways driving various cellular functions. Over the last decade, considerable progress has been made in understanding the molecular functions of cellular PAs (Wang and Casero, 2006). In plant organs, PAs are positively implicated in plant growth and differentiation as well as in stress responses. In plant tissues, the PAs are putrescine (1, 4-diaminobutane), spermidine (N-3-aminopropyl-1, $\quad 4$ diaminobutane) and spermine [bis (N-3aminopropyl-1, 4-diaminobutane)]. The three PAs are present ubiquitously as polycationic compounds and are found in significant amounts in cell types to support a wide variety of cellular functions (Wang and Casero, 2006). PAs are potent inhibitors of many senescence-related processes in a variety of plant species and their relative effectiveness as antisenescent agents corresponds to the number of positive charges per molecule; Spm (triamine), which is more effective than Put (diamine) (Galston and Kaur-Sawhney, 1987). Much of this antisenescent activity may be membrane related (Ballas et al., 1983) and this interaction serves to stabilize the bilayer surface and may thus retard membrane deterioration. PAs also have free-radicalscavenging properties (Drolet et al., 1986). Protection of membranes from peroxidation by PAs could involve both their ability to interact with phospholipids and their antioxidant activity. Given the relationship between PAs and membrane protection, and between $\mathrm{CI}$ and membrane damage, the possible connection between PAs and CI is of great interest.

Pre-storage hot water dipping (HWD) of fruit has been investigated as a way of enhancing fruit resistance to CI (Lurie, 1998). A $38^{\circ} \mathrm{C}$ postharvest heat treatment can inhibit ripening of tomato fruit (Lurie et al., 1996) by inhibiting the synthesis of the enzymes involved in the ripening processes, including those involved in ethylene synthesis and fruit softening. This inhibition is removed once the temperature is lowered. In addition, a postharvest heat treatment applied prior to low temperature storage can reduce the incidence of $\mathrm{CI}$ in cold sensitive fruits, such as mango (McCollum et al., 1993) and persimmon (Lay-Yee et al., 1997).

Post-harvest application of PAs, by vacuum or immersion infiltration, has been reported to delay fruit ripening and extend shelf life in fruits. Keeping these in view the present experiment was carried out.

\section{Materials and Methods}

The experiment was conducted from January 2013 to April 2013. The uniform sized fully matured but unripe fruits of ber cv. 'Gola' at colour turning stage were obtained from Instructional Farm of Krishi Vigyan Kendra, 
SK Rajasthan Agricultural University, Beechwal, Bikaner and brought to the Post Harvest Technology Laboratory of the Department on the next day. Ber fruits were inspected thoroughly for any damage and spoilage. The immature, over mature, spotted and off type fruits were discarded. The selected fruits were thoroughly washed with tap water to remove dirt and dust particles adhering to the surface of fruits. Then fruits are again washed with chlorinated water and allowed to shade dry.

The nine treatment combinations of hot water and polyamines concentration were used to treat the fruits. The treatment applied were: (1) Dipped at $20^{\circ} \mathrm{C}$ hot water + Spermidine $\left(1 \mathrm{mM} \mathrm{L}^{-1}\right)$ for 5 minutes $\left(\mathrm{W}_{1} \mathrm{P}_{1}\right)$; (2) Dipped at $20^{\circ} \mathrm{C}$ hot water + Spermine $\left(1 \mathrm{mM} \mathrm{L}^{-1}\right)$ for 5 minutes $\left(\mathrm{W}_{1} \mathrm{P}_{2}\right)$; (3) Dipped at $20^{\circ} \mathrm{C}$ hot water + Putrescine $\left(1 \mathrm{mM} \mathrm{L}^{-1}\right)$ for 5 minutes $\left(\mathrm{W}_{1} \mathrm{P}_{3}\right)$; (4) Dipped at $35^{\circ} \mathrm{C}$ hot water + Spermidine $\left(1 \mathrm{mM} \mathrm{L}^{-1}\right)$ for 5 minutes $\left(\mathrm{W}_{2} \mathrm{P}_{1}\right)$; (5) Dipped at $35^{\circ} \mathrm{C}$ hot water + Spermine $\left(1 \mathrm{mM} \mathrm{L}^{-1}\right)$ for 5 minutes $\left(\mathrm{W}_{2} \mathrm{P}_{2}\right)$; (6) Dipped at $35^{\circ} \mathrm{C}$ hot water + Putrescine $\left(1 \mathrm{mM} \mathrm{L}^{-1}\right)$ for 5 minutes $\left(\mathrm{W}_{2} \mathrm{P}_{3}\right)$; (7) Dipped at $45^{\circ} \mathrm{C}$ hot water + Spermidine $\left(1 \mathrm{mM} \mathrm{L}^{-1}\right)$ for 5 minutes $\left(\mathrm{W}_{3} \mathrm{P}_{1}\right)$; (8) Dipped at $45^{\circ} \mathrm{C}$ hot water + Spermine $\left(1 \mathrm{mM} \mathrm{L}^{-1}\right)$ for 5 minutes $\left(\mathrm{W}_{3} \mathrm{P}_{2}\right)$; (9) Dipped at $45^{\circ} \mathrm{C}$ hot water + Putrescine $\left(1 \mathrm{mM} \mathrm{L}^{-1}\right)$ for 5 minutes $\left(\mathrm{W}_{3} \mathrm{P}_{3}\right)$. Therefore, total 9 treatment combinations were used in this experiment. The treated fruits were stored at $6^{\circ} \mathrm{C}$ temperature in cold storage.

\section{Methodology used for observations}

After applying treatments, the subsequent observations on enzymatic activity and chilling injury index were recorded at 7 days interval. The following observations were recorded during the course of investigation. Polygalacturonase (PG) (EC. 3.2.1.15) was extracted by the method of Zainon and Brady (1982) with slight modifications, Extraction and assay of Polyphenol oxidase (PPO) (EC. 1.14.18.1) was carried out as described by Matta and Dimond (1963), Extraction and assay of Phenylalanine ammonia lyase (PAL) (EC. 4.3.1.5) was carried out as described by Rao and Towers (1970) and Chilling injury index was determined with a five point hedonic scale based on the surface area of fruit affected by water soaked lesions, pitting and skin discolouration (Gonzalez-Aguilar $e t$ al., 1997).

\section{Results and Discussion}

\section{Polygalacturonase (PG)}

Put at $1.0 \mathrm{mM}$ concentrations was the most effective among all three polyamines treatments. PAs are able to bind negatively charged molecules like pectic polysaccharides (Bagni and Pistochi, 1990). The formation of pectin-PAs complexes in the cell wall would make pectin less accessible to PG attack. PAs also inhibits biosynthesis of ethylene in plants (Flores et al., 1990) and the activation of transcription of the PG gene occurs after ethylene synthesis (Seymur et al., 1993).

Delayed fruit softening in Put-treated fruit may be ascribed to the reduction in the activities of fruit softening enzymes such as PG. It has been reported that PG enzyme is primarily responsible for ripening associated pectin degradation and fruit softening (Brady, 1987). PME catalyses the softening process through desertification of pectin followed by pectin depolymerisation, catalysed by PG (Roe and Bruemmer, 1981). The lowest PG activity in treatment combinations was recorded in hot water at $45^{\circ} \mathrm{C}$ for 5 minutes + putrecsine $\left(1 \mathrm{mM} \mathrm{L}^{-1}\right)$ and maximum in water treatment at $20^{\circ} \mathrm{C}$ water for 5 minutes + spermidine $\left(1 \mathrm{mM} \mathrm{L}^{-1}\right)$ (Table 1$)$. The PG activity increased apparently during storage period from 1 to 35 days in all the treatment studied. 


\section{Polyphenol oxidase (PPO)}

The PPO activity of ber fruits increased during storage and their values were significantly lowered by $45^{\circ} \mathrm{C}$ hot water and putrecsine treatment and their combination (Table 2). Hot water treatment at $45^{\circ} \mathrm{C}$ was found to be most effective over other hot water treatments to prevent the increase in PPO activity. Hot water treatment for $10 \mathrm{~min}$ at $35^{\circ} \mathrm{C}$ markedly lowered the PPO activity of jujube fruit (Promyou et al., 2012). The heat treatment effectively reduced the membrane damage and skin darkening of jujube fruit under chilling storage. Promyou et al., (2008) reported that the application of hot water treatment reduced the activity of PPO in 'Gros Michel' and 'Namwa' banana and a reduction in gene encoding of PPO was detected in the hot-water-treated fruit.

PAs treatments alone and combined with hot water treatments was significantly inhibited the activity of PPO.

Table.1 Interaction effect of hot water and polyamine treatments on polygalacturonase activity $\left(\mu \mathrm{g} \mathrm{g}^{-1}\right)$ during storage

\begin{tabular}{llllll}
\hline \multirow{2}{*}{$\begin{array}{l}\text { Treatment } \\
\text { combination }\end{array}$} & $\mathbf{7}$ & $\mathbf{1 4}$ & $\mathbf{2 1}$ & $\mathbf{2 8}$ & $\mathbf{3 5}$ \\
\cline { 2 - 6 } $\mathrm{W}_{1} \mathrm{P}_{1}$ & 192.60 & 193.30 & 197.90 & 202.40 & 225.20 \\
$\mathrm{~W}_{1} \mathrm{P}_{2}$ & 187.30 & 187.50 & 189.50 & 189.70 & 198.20 \\
$\mathrm{~W}_{1} \mathrm{P}_{3}$ & 138.40 & 180.60 & 183.10 & 187.10 & 192.66 \\
$\mathrm{~W}_{2} \mathrm{P}_{1}$ & 137.20 & 164.15 & 179.86 & 180.40 & 180.96 \\
$\mathrm{~W}_{2} \mathrm{P}_{2}$ & 129.60 & 135.70 & 159.30 & 167.80 & 177.60 \\
$\mathrm{~W}_{2} \mathrm{P}_{3}$ & 106.60 & 128.80 & 135.60 & 150.30 & 151.30 \\
$\mathrm{~W}_{3} \mathrm{P}_{1}$ & 85.90 & 96.60 & 97.40 & 125.70 & 145.40 \\
$\mathrm{~W}_{3} \mathrm{P}_{2}$ & 84.90 & 89.40 & 95.40 & 102.30 & 110.60 \\
$\mathrm{~W}_{3} \mathrm{P}_{3}$ & 76.50 & 79.90 & 82.40 & 87.60 & 89.70 \\
$\mathrm{SEm} \pm$ & 1.87 & 2.10 & 2.27 & 2.50 & 2.63 \\
$\mathrm{CD}(\mathrm{P} \leq 0.05)$ & 5.56 & 6.25 & 6.73 & 7.42 & 7.82 \\
\hline
\end{tabular}

Table. 2 Interaction effect of hot water and polyamine treatments on polyphenol oxidase (PPO) activity (OD at $400 \mathrm{~nm}$ ) during storage

\begin{tabular}{llllll}
\hline \multirow{2}{*}{$\begin{array}{l}\text { Treatment } \\
\text { combination }\end{array}$} & $\mathbf{7}$ & $\mathbf{1 4}$ & $\mathbf{2 1}$ & $\mathbf{2 8}$ & $\mathbf{3 5}$ \\
\cline { 2 - 6 } $\mathrm{W}_{1} \mathrm{P}_{1}$ & 0.206 & 0.215 & 0.219 & 0.226 & 0.245 \\
$\mathrm{~W}_{1} \mathrm{P}_{2}$ & 0.164 & 0.175 & 0.208 & 0.210 & 0.211 \\
$\mathrm{~W}_{1} \mathrm{P}_{3}$ & 0.125 & 0.134 & 0.157 & 0.167 & 0.186 \\
$\mathrm{~W}_{2} \mathrm{P}_{1}$ & 0.093 & 0.098 & 0.154 & 0.159 & 0.172 \\
$\mathrm{~W}_{2} \mathrm{P}_{2}$ & 0.092 & 0.093 & 0.145 & 0.158 & 0.163 \\
$\mathrm{~W}_{2} \mathrm{P}_{3}$ & 0.081 & 0.083 & 0.113 & 0.152 & 0.156 \\
$\mathrm{~W}_{3} \mathrm{P}_{1}$ & 0.069 & 0.070 & 0.112 & 0.113 & 0.128 \\
$\mathrm{~W}_{3} \mathrm{P}_{2}$ & 0.065 & 0.067 & 0.109 & 0.114 & 0.126 \\
$\mathrm{~W}_{3} \mathrm{P}_{3}$ & 0.064 & 0.066 & 0.072 & 0.105 & 0.124 \\
$\mathrm{SEm} \pm$ & 0.002 & 0.003 & 0.002 & 0.003 & 0.002 \\
$\mathrm{CD}(\mathrm{P} \leq 0.05)$ & 0.005 & 0.008 & 0.007 & 0.009 & 0.007 \\
\hline
\end{tabular}


Table.3 Interaction effect of hot water and polyamine treatments on phenylalanine ammonia lyase $(P A L)$ activity ( $\mu$ Moles) during storage

\begin{tabular}{llllll}
\hline \multirow{2}{*}{$\begin{array}{l}\text { Treatment } \\
\text { combination }\end{array}$} & $\mathbf{7}$ & $\mathbf{1 4}$ & $\mathbf{2 1}$ & $\mathbf{2 8}$ & $\mathbf{3 5}$ \\
\cline { 2 - 6 } & 12.46 & 14.60 & 14.89 & 14.96 & 15.67 \\
$\mathrm{~W}_{1} \mathrm{P}_{1}$ & 10.43 & 10.68 & 12.34 & 12.63 & 13.66 \\
$\mathrm{~W}_{1} \mathrm{P}_{2}$ & 9.92 & 10.23 & 12.23 & 12.60 & 13.00 \\
$\mathrm{~W}_{1} \mathrm{P}_{3}$ & 9.43 & 10.13 & 12.07 & 12.55 & 12.99 \\
$\mathrm{~W}_{2} \mathrm{P}_{1}$ & 9.26 & 10.12 & 10.37 & 11.99 & 12.30 \\
$\mathrm{~W}_{2} \mathrm{P}_{2}$ & 8.86 & 9.97 & 10.36 & 11.25 & 12.12 \\
$\mathrm{~W}_{2} \mathrm{P}_{3}$ & 8.79 & 9.85 & 10.36 & 10.95 & 11.97 \\
$\mathrm{~W}_{3} \mathrm{P}_{1}$ & 8.74 & 9.77 & 10.30 & 10.80 & 11.38 \\
$\mathrm{~W}_{3} \mathrm{P}_{2}$ & 8.62 & 9.40 & 9.66 & 10.13 & 11.08 \\
$\mathrm{~W}_{3} \mathrm{P}_{3}$ & 0.15 & 0.17 & 0.19 & 0.19 & 0.21 \\
$\mathrm{SEm} \pm$ & 0.45 & 0.51 & 0.56 & 0.57 & 0.61 \\
$\mathrm{CD}(\mathrm{P} \leq 0.05)$ & & & &
\end{tabular}

Table.4 Interaction effect of hot water and polyamine treatments on chilling injury index (five point hedonic scale) during storage

\begin{tabular}{llllll}
\hline $\begin{array}{l}\text { Treatment } \\
\text { combination }\end{array}$ & $\mathbf{7}$ & $\mathbf{1 4}$ & $\mathbf{2 1}$ & $\mathbf{2 8}$ & $\mathbf{3 5}$ \\
\cline { 2 - 6 } $\mathrm{W}_{1} \mathrm{P}_{1}$ & -- & -- & 0.43 & 1.07 & 1.34 \\
$\mathrm{~W}_{1} \mathrm{P}_{2}$ & -- & -- & 0.40 & 0.98 & 1.28 \\
$\mathrm{~W}_{1} \mathrm{P}_{3}$ & -- & -- & 0.00 & 0.73 & 1.00 \\
$\mathrm{~W}_{2} \mathrm{P}_{1}$ & -- & -- & 0.00 & 0.70 & 0.95 \\
$\mathrm{~W}_{2} \mathrm{P}_{2}$ & -- & -- & 0.00 & 0.51 & 0.82 \\
$\mathrm{~W}_{2} \mathrm{P}_{3}$ & -- & -- & 0.00 & 0.43 & 0.60 \\
$\mathrm{~W}_{3} \mathrm{P}_{1}$ & -- & -- & 0.00 & 0.40 & 0.54 \\
$\mathrm{~W}_{3} \mathrm{P}_{2}$ & -- & -- & 0.00 & 0.31 & 0.44 \\
$\mathrm{~W}_{3} \mathrm{P}_{3}$ & -- & -- & 0.00 & 0.08 & 0.10 \\
$\mathrm{SEm} \pm$ & -- & -- & 0.02 & 0.01 & 0.01 \\
$\mathrm{CD}(\mathrm{P} \leq 0.05)$ & -- & -- & 0.06 & 0.02 & 0.04 \\
\hline
\end{tabular}

However, at heat treatment conditions of $60^{\circ} \mathrm{C}, 60 \mathrm{~min}$, there was a significant decrease in PPO activity (Ciou et al., 2011). Dogan and Dogan (2004) reported that optimum temperature for PPO was within the range of $25-45^{\circ} \mathrm{C}$, respectively, depending upon the substrate and $\mathrm{pH}$-value.

Dogan and Dogan (2004) reported that high temperatures $\left(70^{\circ} \mathrm{C}\right)$ and long heating times with various substrates significantly decreased PPO activity.

\section{Phenylalanine Ammonia Lyase (PAL)}

PAL activity increased irrespective of treatments in the storage duration. As shown in (Table 3), PAL activity was significantly lowers $(p<0.05)$ in fruits treated with $45^{\circ} \mathrm{C}$ hot water and Put $1 \mathrm{mM} \mathrm{L}^{-1}$ than other water treatments $\left(20^{\circ} \mathrm{C}\right.$ and $\left.35^{\circ} \mathrm{C}\right)$ and PAs (Spd and $\mathrm{Spm}$ ) treatment combinations on all the storage days. In this study, PAL activity was lower in both hot water and PAs treatments. This suggests that the activity of PAL might 
be associated with chilling tolerance in ber fruits. There are few reports on the relationship between PAL activity and heat induced chilling tolerance in harvested fruit (Martinez-Tellez and Lafuente, 1997). PAL activity can be induced by various stresses, such as chilling (Lafuente et al., 2003), wounding (Campos-Vargas et al., 2005) and plant harmone including ethylene, jasmonic acid and salicylic acid (Campos-Vargas and Saltveit, 2002).

\section{Chilling Injury Index (CII)}

Chilling injury symptoms were seen in 35 and $45^{\circ} \mathrm{C}$ hot water treated fruits after 28 days of storage whereas it was appeared slightly earlier in fruits dipped in $20^{\circ} \mathrm{C}$ hot water i.e., on $21^{\text {st }}$ day of storage (Table 4). The symptoms characterized by the purplish colour on fruit skin, water soaked lesions, pitting in advance stage and uneven ripening. Chilling injury index (CII) increased sharply after 21 days of storage. Pre storage heat treatments (both hot air and hot water treatments) are widely accepted as effective in the control of decay and insect activity in fresh commodities (Lurie, 1998). In addition, heat treatments have been reported as a potential method to reduce chilling injury in persimmon (Lay-Yee et al., 1997) and pomegranate (Mirdehghan and Rahemi, 2005). González- Aguilar et al., (2000) reported that the reduction in chilling injury of hot-water-treated pepper fruit was clearly related to the high levels of polyamines. Moreover, the application of heat treatments to reduce $\mathrm{CI}$ in fruit has been reported for 'Valencia' oranges (Bassal and El-Hamahmy, 2011) and pomegranate (Mirdehghan and Rahemi, 2005).

This study indicates that 'Gola' ber fruit can be stored at $6^{\circ} \mathrm{C}$ for 35 days with using $\mathrm{W}_{3} \mathrm{P}_{3}$ $\left(45^{\circ} \mathrm{C}\right.$ hot water + putrescine $\left.1 \mathrm{mM} \mathrm{L}^{-1}\right)$ treatment combination (dipping of fruits for 5 min) and maintains ripening associated enzymatic activity with minimum chilling injury index. This standardized storage technology has promising future for technology utilization by small, medium and large scale processors and entrepreneurs.

\section{References}

Anonymous. 2009. Vital Horticulture Statistics. Directorate of Horticulture, Pant Krishi Bhawan, Government of Rajasthan. Pp. 2.

Bagni, N. and Pistochi, R. 1990. Binding, transport and subcelullar compartmentation of polyamines in plants. In: Polyamines and Ethylene: Biochemistry, Physiology and Interactions. (Flores, H.E., Arteca, R.N. and Shannon, S. Eds.). American Society of Plant Physiologist, Maryland, USA. Pp. 62-63.

Bal, J.S. and Mann, S.S. 1978. Ascorbic acid content of ber (Ziziphus mauritiana Lamk.) during growth and maturity. Science and Culture, 44: 238-239.

Ballas, S.K., Mohandas, N., Marton, L.J. and Shohet, S.B. 1983. Stabilization of erythrocyte membranes by polyamines. Proceedings of the National Academy of Sciences, 80: 1942-1946.

Bassal, M. and El-Hamahmy, M. 2011. Hot water dip and preconditioning treatments to reduce chilling injury and maintain postharvest quality of Navel and Valencia oranges during

Brady, C.J. 1987. Fruit ripening. Annual Reviews of Plant Physiology, 38: 155178.

Campos-Vargas, R. and Saltveit, M.E. 2002. Involvement of putative chemical wounded lettuce. Physiologia Plantarum, 114: 73 -84.

Campos-Vargas, R., Nonogaki, H., Suslow, T. and Saltveit, M.E. 2005. Heat shock treatments delay the increase in wound- 
induced phenylalanine ammoniaammonia-lyase activity by altering its expression, not its induction in Romaine lettuce (Lactuca sativa) tissue. Physiologia Plantarum, 132: 82-91.

Ciou, J.Y., Lin, H.H., Chiang, P.Y., Wangd, C.C. and Charles, A.L. 2011. The role of polyphenol oxidase and peroxidase in the browning of water caltrop pericarp during heat treatment. Food Chemistry, 127: 523-527.

Dogan, S. and Dogan, M. 2004. Determination of kinetic properties of polyphenol oxidase from Thymus (Thymus longicaulis subsp. chaubardii var. chaubardii). Food Chemistry, 88: 69-77.

Drolet, G., Dumbroff, E.B., Legge, R.L. and Thompson, J.E. 1986. Radical scavenging of polyamines. Phytochemistry, 25: 367-371.

Flores, H. E., Arteca, R. N. and Shannon, J. C. 1990. Polyamines and ethylene: biochemistry, physiology, and interactions. American Society of Plant Physiologists, Rockville, Maryland, USA. Pp. $\mathrm{xv}+425$.

Galston, A.W. and Kaur-Sawhney, R. 1987. Polyamines and senescence in plants. In: Plant Ssenescence: its Biochemistry and Physiology. (Thomson, W.W., Nothnagel, E.A. and Huffaker R.C. Eds.). Rockville, Maryland: American Society of Plant Physiologists, Pp. 167181.

González-Aguilar, G.A., Zacarias, L., Mulas, M. and Lafuente, M.T. 1997. Temperature and duration of water dips influence chilling injury, decay and polyamine content in 'Fortune' mandarins. Postharvest Biology and Technology, 12: 61-69.

Gonzalez-Aguilar, G.A., Gayosso, L., Cruz, R., Fortiz, J., Baez, R. and Wang, C.Y. 2000. Polyamines induced by hot water treatments reduce chilling injury and decay in pepper fruit. Postharvest Biology and Technology, 18: 19-26.

Jat, L., Pareek, S. and Shukla, K.B. 2013. Physiological responses of Indian jujube (Ziziphus mauritiana Lamk.) fruit to storage temperature under modified atmosphere packaging. Journal of the Science of Food and Agriculture, 93: 1940-1944.

Jawanda, J.S., Bal, J.S., Josan, J.S. and Mann, S.S. 1981. Ber cultivation in Punjab. Punjab Horticultural Journal, 21: 1722.

Lafuente, M.T., Zacarias, L., Martinez-Telez, M.A., Sanchez-Ballesta, M.T. and Granell, A. 2003. Phenylalanine ammonia-lyase and ethylene in relation to chilling injury as affected by fruit age in citrus. Postharvest Biology and Technology, 29: 308-317.

Lay-Yee, M., Ball, S., Forbes, S.K. and Woolf, A.B. 1997. Hot water treatment for insect disinfestations and reduction of chilling injury of 'Fuju' persimmon. Postharvest Biology and Technology, 10: 81-87.

Lay-Yee, M., Ball, S., Forbes, S.K. and Woolf, A.B. 1997. Hot water treatment for insect disinfestations and reduction of chilling injury of 'Fuju' persimmon. Postharvest Biology and Technology, 10: 81-87.

Lurie, S. 1998. Postharvest heat treatments. Postharvest Biology and Technology, 14: 257-269.

Lurie, S., Handros, A., Fallik, E. and Shapira, R. 1996. Reversible inhibition of tomato fruit gene expression at high temperature. Plant Physiology, 110: 1207-1214.

Martinez-Tellez, M.A. and Lafuente, M.T. 1997. Effect of high temperature conditioning on ethylene, phenylalanine ammonia-lyase, peroxidase and polyphenol oxidase activities in flavedo of chilled 'Fortune' mandarin fruit. 
Journal of Plant Physiology, 150: 674678.

Matta, A. and Dimond, A.E. 1963. Symptoms of Fusarium wilt in relation to quantity of fungus and enzyme activity in tomato stems. Phytopathology, 53: 132-136.

McCollum, T.G., Aquino, S.D. and McDonald, R.E. 1993. Heat treatment inhibits mango chilling injury. Journal of Horticultural Sciences, 28: 197-198.

Mirdehghan, S.H. and Rahemi, M. 2005. Effects of hot water treatment on reducing chilling injury of pomegranate (Punica granatum) fruit during storage. Acta Horticulturae, 682: 887-892.

Mirdehghan, S.H., Rahemi, M., MartinezRomero, D., Guillen, F., Valverde, J.M., Zapata, P.J., Serrano, M. and Valero, D. 2007a. Reduction of pomegranate chilling injury during storage after heat treatment: Role of polyamines. Postharvest Biology and Technology, 44: 19-25.

Morton, J.F. 1987. Indian jujube. In: Fruits of Warm Climates. Julia F. Morton 20534 SW 92 Ct., Miami, Florida, Pp. 272275.

Pareek, O.P. 1983. The Ber. Indian Council of Agricultural Research, New Delhi. Pp. 5.

Pareek, S. and Yahia, E.M. 2013. Postharvest biology and technology of ber. Horticultural Reviews, 41: 1-31.

Pareek, S., Fageria, M.S. and Dhaka, R.S. 2002. Performance of ber genotypes under arid condition. Current Agriculture, 26: 63-65.

Pareek, S., Kaushik, R.A. and Rathore, N.S. 2009a. A value chain on commercial exploitation of underutilized fruits of tribal zones of Rajasthan. National Agricultural Innovation Project, Department of Horticulture, Rajasthan College of Agriculture, MPUAT, Udaipure. Pp. 20.

Promyou, S., Ketsa, S. and Van-Doorn. W.G.S. 2008. Hot water treatment delay cold-induced banana peel blackening. Postharvest Biology and Technology, 48: $132-138$.

Promyou, S., Supapvanich, S., Boodkord, B. and Thangapiradeekajorn, M. 2012. Alleviation of chilling injury in jujube fruit (Ziziphus jujuba Mill) by dipping in $35^{\circ} \mathrm{C}$ water. Kasetsart Journal of Natural Sciences, 46: 107-119.

Rao, P.V.S. and Towers, G.H. 1970. LPhenylalanine ammonia lyase (Ustilago nuda). In: Methods in Enzymology, (Colowick, S.P. and Kaplan N.O. Eds), vol. XVIIA. Pp. 581- 585.

Roe, B. and Bruemmer, J.H. 1981. Changes in pectin substances and enzyme during ripening and storage of 'Keitt' mango. Journal of Food Science, 54: 186-189.

Seymur, A., Taylor, J.E. and Tucker, E. 1993. Biochemistry of Fruit Ripening, Chapman and Hall, USA. Pp. 16-21, 423-429.

Wang, J.Y. and Casero, R.A. 2006. Polyamine Cell Signaling. Humana Press Inc, New Jersey.

Zainon, M.A. and Brady, C.J. 1982. Purification and characterisation of the polygalacturonase of tomato fruit. Australian Journal of Plant Physiology, 9: 155-169.

\section{How to cite this article:}

Hukam Raj Saini, Sunil Pareek, D.K. Sarolia and Mukesh Nagar. 2017. Effect of Hot Water Dipping and Polyamines on Activity of Ripening Enhancer Enzymes during Storage of Ber. Int.J.Curr.Microbiol.App.Sci. 6(11): 1605-1612. doi: https://doi.org/10.20546/ijcmas.2017.611.192 